\title{
The Teaching of Speaking in Big Classes
}

\author{
Ruwandi \\ English Department of Educational Faculty \\ State Islamic Studies Institute (STAIN) Salatiga \\ Jl. Tentara Pelajar No. 02 Salatiga, Central Java, Indonesia \\ pakruwandy@gmail.com
}

\begin{abstract}
Speaking is the most important language skill. The language user's capability will be immediately understood and measured through the skill because this is the most visible proficiency. Difficulties of teaching speaking vary dependent upon the class size. Teaching speaking in big classes is more difficult than teaching of it in small classes. The main constraint is the time allotment. To answer the problem, speaking teachers should be creative to set the intensive classroom activities. If this is true, they need to identify students speaking skill to understand their alertness for the following language instructions. Besides that, they are also responsible to identify their basic need in the class whether this is only for question and answer, dialog, discussion, debate, or others. To anticipate the time constraints, the teachers engage to select the possible methods and strategies for presenting the interesting instructional materials. At the end, teachers should divide the time allotment adjust and proportionally for their students so they are able to selfexpress and share ideas in those interactive classroom situations.
\end{abstract}

Keywords: Speaking, Existing Skill, Need Analysis, Classroom Management, Methods and Strategies, Presentation

\begin{abstract}
Abstrak
Berbicara (speaking) adalah ketrampilan bahasa yang paling penting. Kemampuan pengguna bahasa akan segera dimengerti dan diukur melalui ketrampilan tersebut karena ini adalah keahlian yang paling nampak. Kesulitan mengajar speaking itu bervariasi tergantung ukuran kelasnya. Mengajar speaking di kelas besar lebih sulit daripada mengajarnya di kelas kecil. Ketidakleluasaan yang utama adalah pemberian waktu. Untuk menjawab masalah ini, pengajar speaking harus kreatif untuk mengatur kegiatan kelas yang intensif. Jika ini tepat, mereka harus mengdentifikasi ketrampilan speaking peserta didik untuk memahami kesiapan terhadap
\end{abstract}


instruksi bahasa selanjutnya. Selain itu, mereka juga harus bertanggungjawab untuk mengidentifikasi kebutuhan dasar mereka di kelas apakah ini hanya untuk pertanyaan dan jawaban, dialog, diskusi, debat atau yang lainnya. Untuk mengantisipasi ketidakleluasaan waktu, pengajar mengatur untuk memilih metode dan strategi yang memungkinkan untuk menampilkab instruksi materi yang menarik. Untuk yang terakhir, pengajar harus membagi pengaturan pemberian waktu secara proporsional untuk peserta didik mereka agar mereka dapat mengekspresikan diri dan mengungkapkan gagasan di dalan situasi kelas yang interaktif tersebut.

Kata Kunci: Berbicara/Speaking, Ketrampilan yang Nampak, Manajemen Kelas, Metode dan Strategi, Presentasi

\section{Introduction}

Speaking is one of the productive skills in language study. Learners' skill in speaking is directly understood or measured whether they are productive or not. Accordingly, they are called skillful if they always produce utterances through their vital organ of speech namely mouth. Conversely, if they just keep silent all the time whether in training, practice or in a speech community, they are called unskillful. Thus, opening mouth and sharing ideas are the keys of speaking. For the reason, speaking is also called oral skill because speakers use the spoken forms of language not the written words. The former is significantly different from the latter.

Teaching speaking is different from teaching the other language skills. There are several factors, which should be paid by speaking teachers. One of them is, for instance, this is absolutely individuals' concern. The evaluation of it should be addressed to the student-selves and not others. Besides that, it is also direct so the students' quality is also directly measured. By the time, they will be directly seen as skillful or unskillful students after sharing ideas in front of the assessors or audiences. 
The teaching of speaking will be more and more difficult when students and teachers join big classes with the very limited time allotment. Teachers, particularly, should divide the time allotment to all individuals if they like them to get the same or equal time durations. In addition, they should be sure that the individuals have the same opportunity to take part in the process. Time division, however, is not the end of the problems because even though the students have gotten the average opportunity to do so but the time to do is still insufficient. How teachers share the sufficient time allotment if the class consists of 30 until 50 students. When the time allotment covers 90 minutes, and there are 30 pupils in the class, alias a student will have three minutes to speak. The problems of teaching speaking will be more complicated if the class begins very late because both teachers and students also attend the class late. This becomes more difficult when the students are unready to come in and join that class. They may come with empty mind and unready to speak. When the limited time allotment is added by such conditions, teachers should think of it skillfully.

Still, teachers have extra jobs when students are unmotivated to speak. They should energize them to open mouth and say anything. Moreover, this is not an easy job to do. Sometimes they should share rewards: fair, good, excellent, and so forth; even though their students only produce a few words. This is the only way to persuade the students to do so and to progress the class. However, this is not the end of the efforts when some students still keep silent.

West (1966: 1) categorizes big classes as one of the unfavorable circumstances. He says by 'unfavorable circumstances' means that a class comprises of over thirty, forty, fifty pupils or more, seated on benches not sitting at individual or dual desks. They are gathered in an unsuitably shaped room, ill graded, with a teacher who perhaps does not speak English very 
well or very fluently, working in a hot climate. Such a kind of the class is of course very stressful, moreover if that class is set forth the teaching of speaking. How to move the students when there are 30 or perhaps 50 students in the speaking class while the class must be mobiled because students need to share ideas in multi-directions. This is also very impossible to move benches and even though they are moved, the form of the class is still stable. In addition, it will time and energy consuming when the class is used together with the other classmates and other subjects. Therefore, it is fair to say that such the class belongs to unfavorable circumstance.

Big classes, particularly, are still dominant in most Indonesian institutions. Occasionally, there are more than twenty students in Indonesian elementary classrooms and thirty until forty pupils or more in junior or senior high school institutions. Such a kind of class setting is considered because of several facts. The most common reasons that often appear are for example: the lack of human resources so the number of teachers is insufficient; the shortage of financial supports, and this is also for efficiency. Accordingly, to achieve the satisfactory results is challenging in such conditions. Whatever the reasons, however, teachers should make effective anticipations to the betterment process and result of speaking.

Since big classes still characterize the class form or setting in Indonesian school institutions, teachers should think skillfully to conduct the teaching of speaking effectively. There are several stages, which should be considered before conducting the teaching of speaking. Teachers should, for instance, identify the students' existing skills. Secondly, they should professionally organize the big classes in order to be effective. Then, they should select the appropriate methods to be used, and design the teaching learning processes. In addition, the last they should invite students to involve considering their success through individual or group assignment. 


\section{Discussion}

\section{Students' Existing Skills}

In professional class setting, identification of students' existing skills is very useful for the language study. This is not only to understand the students' previous existing skills but also to redesign or reconsider the following course design. There are several advantages, which can be taken from the identification. The first result is it is necessary to design course materials and their level of difficulties. Besides, it is also useful to consider the methods used. In addition, the last but not the least, the identification will be influential to determine course objective, the teaching and learning activities, and the like.

Speaking teachers are able to identify students' existing skills through several ways. They are, for instance, able to identify their previous skills through their previous academic records in such a skill if they have ever sat at or join speaking class. When this identification is insufficient, the teachers are able to invite students to converse. By conducting conversation, that means they are interviewing the candidates. The interview can be accomplished in formal or in informal situations. However, this should not be undertaken at glance because they should completely understand the students' prepared skills.

When speaking teachers are going to get standardized identification, however, they should hold standardized test. There are a few forms of standardized test administrations, which can be conducted to understand the students' existing skills. To get the wished, fix-test result of a language test, teachers must establish its purpose or function. The establishment of the purpose becomes important because there are several standardized tests. Each

test has its specific characteristics and objectives. The accomplishment of the test without such considerations can be disadvantages. 
David P. Harris (1969) proposes several models of standardized test in language teaching. Among of the models are as follows:

\section{Selection Test}

Selection test is used to determine readiness for instructional programs. Some screening tests are used to separate those who are ready for academic or training program from those who are unready. The purpose of the selection test is to determine a single cutoff objective: examinees either "pass" or "fail", the test. The degree of success or failure, however, is not important.

This prognostic test is influential to set forth the readiness of students. It is better that the students also understand whether they are ready or unready to join teaching-learning processes. When they are unready, what are the problems and what they should know what they should do after the test? By the result, teachers may persuade the students to prepare themselves. It is also possible if teachers initiate to invite them to sit together to solve their problems.

\section{The Classification Test}

This test is used to classify or place students in appropriate language classes. Sometimes, this kind of screening test tries to distinguish degrees of proficiency. The result of the test is used to assign examinees in specific sections or activities in language study based on their level. Thus, it is not used to make pass-fail distinctions because these are not the purpose of the test. Whatever the level of the students' competence either "low" or "high" is not important. All students whatever their skills, will get certain consideration because training in language is offered to everyone.

3. Diagnostic Test

Diagnostic test is used to diagnose the individual's specific strengths and weaknesses. Diagnose the students' strengths and weaknesses concerning 
their skills are very crucial. This is the fact that students are not all around by which they are not to have the best excellencies in all language skills. It is only a few, who are all around and almost each of them is excellent in a certain skill and posses average abilities on the others. Through the test, teachers are able to diagnose individual students' skills and absolutely understand what a certain skill dominates them and what the average skills they possess. In this case, the teachers are capable of sharpening each skill they possess in accordance with their level. David P. Harris (1969:3) says that diagnostic screening tests generally consist of several shorts but reliable subtests measuring different language skills and components of a single broad skill. Based on the individual's performance on each subtest, teachers are able to plot a performance profile that will show his relative strength in the various areas tested.

\section{Aptitude Test}

Aptitude test is administered to measure students' aptitude for learning. In language study, it can be used to predict what kind of performance expected to be mastered by students. David P. Harris (1969) suggests that at the time of speaking, the examinees may have little or no knowledge of the language to be studied, and the test is employed to assess their potential. Thus it can be administered for those or common people who know nothing. In addition, when they have been joining language classes, it is useful to determine the following level of difficulties, materials, and students' grades.

\section{Achievement Test}

Achievement test is conducted to measure the extent of student achievement of the instructional goals. This is used to asses the instructional objectives proposed before conducting teaching-learning processes. Teachers 
only need to compare the appropriateness between the proposed objectives and the achievement of the test. When the two necessities have been represented, teachers are immediately able to consider that the instructional activities are either successful or not. This is used to measure both individual and group progress about language instruction. It can be administered both in the process and at the end of the program.

6. General proficiency achievement test

This kind of test is used to evaluate the effectiveness of instruction. This is not used to asses the degree of success of individual but the instructional program itself. By the test teachers and for some extent researchers understand the effectiveness of teaching program. It is useful for the researchers because they will understand not only the teaching goals but also the teaching instruments as materials and techniques used to achieve them.

For simplicity, David P. Harris (1969) groups the forgoing six categories into three headings. The first is aptitude test (category 4 above); the second is general proficiency (categories 1,2, and 3); and the last is achievement test (categories 5 and 6). The first one serves to indicate an individual's facility for acquiring specific skills and learning. The general proficiency test indicates what an individual is able to do now as the result of his cumulative learning experiences, though it may also be used to serve as the basis for predicting the students' future attainment. Moreover, the last indicates the extent by which a student has mastered the specific skills or body of information acquired in a formal learning situation.

By the identification, speaking teachers are able to choose one of the test divisions useful for their students. It is the fact that not all measurement specialists use this three-way division of the tests. The main consideration 
that should be taken into account is what kind of a class the speaking teachers like very much to set. If they want to understand the readiness of the students to join class, they only need a selection test. Conversely, if they do not want to know the readiness but the level of students' ability, they should administer proficiency test and not selection test. Perhaps they have had preassumption that all students have been ready to follow classroom instruction. Thus, the consideration of conducting the other screening test divisions is the same as the previous consideration of the two earlier test administrations. Unless, the administration of the test will be meaningless as well as time, energy and money consuming.

\section{Students' Needs Analysis}

After diagnosing students' existing skills, teachers are still responsible to make clear what the students' needs in their language learning are. The responsibility for determining and responding the learners' language needs will assist them to make instructional commands more effective and efficient in terms of learning target. By the considerations, they can specify, grade, and present the materials in continual and successful paces. Richards (1992) suggests that student need analysis can be conducted informally and personally through one-to-one sessions with students, by which teachers talk about several issues as the students' perception of their learning styles, learning assets, and learning goals. The analysis, however, can be done formally through administering a needs assessment instruments.

The questions of what students' need should one of the crucial steps in determining learning objectives. Graves (1996) asks one important question concerning the need analysis. The question is; what is needs assessment, and why teachers should undertake it? He says that needs assessment involves finding out what the learners know and can do, and what 
they need to learn and to do so that the course can bridge the gap. Therefore, needs assessment involves seeking and interpreting information about students' needs so the course will go on effectively.

The problems come when teachers should consider students' needs. Quoting Richterich, Graves (1996) shows two different students' needs namely objective and subjective needs. Brindley cited by Graves (1996) defines objective needs as "derivable from different kinds of factual information of (1) learners, (2) their use of language in daily communication activities, and (3) their current language proficiency and language difficulties. The subjective needs are more personal because they are as the cognitive and affective needs of the learners in learning situations. These deal with affective and cognitive factors such as (1) personality, (2) confidence, (3) attitudes, (4) learners' wants, and expectations with regard to the learning of English, and (5) their individual cognitive style and learning strategies.

Graves (1996) suggests that in assessing objective needs teachers may include (1) students' backgrounds as their country and culture, education, family, profession, age, and language spoken; (2) students' abilities or proficiency in understanding, speaking, reading, and writing English; and (3) the students' needs with respect to how they will use or deal with English outside of the classroom. In assessing subjective needs, teachers may include information of (1) students' attitudes towards the target language and culture, towards learning, and towards themselves as learners; (2) students' expectations of themselves and of the course; (3) students' purposes - or lack thereof - in studying English; and (4) students' preferences with respect to how they will learn.

Needs analysis is important because students have different needs in language learning. The result of needs analysis can be used to help teacher consider what is to be taught and how to teach. For example, students who sit 
in English-speaking class need to achieve oral mastery. To achieve the goal, they must be directed to gradual and applicable practices; and should leave several language accuracies as pronunciation and grammatical structures. The achievement of pronunciation and grammatical accuracies, therefore, must be postponed until they are ready with the comprehensible inputs of pronunciation (Krashen and Terrell cited by Richards, 1992: 132) and grammatical structures. On the contrary, they must be promoted to enrich the language vocabularies because they are central in the oral use of language. As far as they speak meaningfully, they can be let as they are by the gradual betterment of their pronunciation and grammar.

Conversely, if students sit in grammar class and should join the grammar tests both for institutional or formal objectives they must engage to the serious study of grammar. Excuses are not permitted for grammatical mistakes because it is an axiom as the rules of math. Deductive and inductive approaches or the mix between the approaches should bring them to the final destination namely the accuracy of grammar mastery. In the study, they may ignore some study of language elements as vocabulary and pronunciation but should be familiar with spelling and orthographic symbols as well as a little language meanings. The necessity to distinguish students' needs in language learning and the conduct of the needs analysis apply to the other language skills and their components to make the language learning more effective and efficient and achieve the respected goals.

Brown and Yule cited by Nunan (1989) suggest that teachers concern to oral skills should confront several questions:

1. What is the appropriate form of the spoken language that is suitable to teach?

2. What should the model of pronunciation be?

3. How far is the importance of the pronunciation? 
4. What is this more important than the teaching of handwriting in that foreign language?

5. Why this is more important?

6. What is the teaching of structures in the oral skills is exactly alike with the teaching of those in written language by a little ignorance in the former?

7. What is it appropriate to teach the same structures to all foreign language learners, no matter what their ages or their intentions are in learning the spoken language?

8. What the standard structures given are those, which should be used in oral expressions?

9. What is it possible to give meaningful practice in the producing spoken English to the students?

Besides considering the previous language components as pronunciation, teachers are responsible to identify student needs in the class. Their needs must be the main determinants for designing teaching and learning objectives. Do they need to concern to transactional or interactional functions of language? Do they need a monologue or dialog? According to Brown and Yule (cited by Nunan, 1993: 27) the distinctions are necessary because transactional functions primarily concern with the transfer of information while interactional functions purpose to maintain the social relationship.

Then, Nunan (1993) affirms that another basic distinction that should be made when developing speaking class is distinguishing between monologue and dialog. The capability to extend an uninterrupted oral presentation is quite different from interacting with one or more other speakers for transactional and interactional purposes. Although all native speakers can and do use language interactionally, but not all of them have the 
capability to extemporize on a given subject to a group of audiences. Brown and Yule (Nunan, 1993:27) affirms that most language teaching deals with developing short skills, by which the learners is only asked to make one or two utterances at a time of interactional exchanges.

\section{Classroom Management}

The next important job of teachers after identifying the students' existing skills and their needs is creating classroom conditions by which the teaching-learning processes take place. This stage is necessary to create to promote such an interactive classroom activities. The creation of the interactive situations aims at achieving the successful class based upon the objectives proposed earlier before the speaking class starts. Teachers are responsible to do so and their skills to the creation and management are held in their hands. Scrivener (1994) suggests the skills of creating and managing a successful class will be the key to the whole success of a course. Therefore, they should pay attention to the job as to achieve the successful course.

According to Scrivener (1994) there are three important parts of teachers' skills to have to do with classroom management. The first is teachers' attitude towards the class setting. In this term, they should believe that a better classroom management would yield the better result and vice versa. Without a good classroom organization, the course may run on conventionally as the most common school situations. For this, teachers may be reluctant to do and does not mean that they are not able to do. Secondly are intentions that direct the teachers' spiritual impulse to start with. By the intentions, they move forwards to design the interactive class by sitting students in multi directive directions. The thought of creating classroom management very depends on the teachers' personality. This closely deals with challenge. If they are challenged to create the better class with the better 
results, they will move forwards. Conversely, if they do not like challenges, they may keep still and give up creating a good classroom management. He says that beside the three teachers' internal impulses, teachers also need certain organizational skills and techniques. He calls the groups of items needed for classroom setting by the heading of 'classroom management'.

Classroom management will improve by the teachers' decisions and actions. Scrivener (1994) defines actions as what is to be performed in the classroom as rearranging the chairs. Teachers arrange chairs to promote and intensify the interactions of the knower and students. The setting depends on the different transmission target. Information transmission must be different from skill practices because the second need the full interaction among the class inhabitants. The following chair setting models can be considered for conducting classroom activities:

1. The Parallel chair setting

This model is useful for information transmission because covering a big class by a large number of students. For language learning, it can be used for pair work. In this model, chairs may be seated parallel from right-left or left-right depends on the position of knowers to front-back into several lines. The teachers may sit at front-left or front-right of the class. All students face to their teachers and could not see their friends behind freely. They just have a little chance to see the right or left-next friends. Students who sit at the back are able to see all their friends at the front but have a little challenge to listen or see. 


\begin{tabular}{|c|c|c|c|}
\hline Students & Students & Students & Students \\
\hline Students & Students & Students & Students \\
\hline Students & Students & Students & Students \\
\hline Students & Students & Students & Students \\
\hline Students & Students & Students & Students \\
\hline
\end{tabular}

Figure 1: Parallel chair setting

2. Horseshoe, half-circle or U chair setting

This is necessary for language practice by which the direction of the class can be multi directives because the students are seated face to face both with their teachers as well as with their co-students. The addressers and the addressees are able to interact together without border. Although teachers sit in the mid of the $\mathrm{U}$, they are movable depends on their roles in the class activities. This can be used for pair or group work, in monologue or dialog, as well as for transactional or interactional activities.

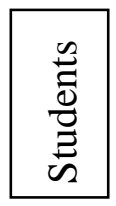

\section{Teacher}
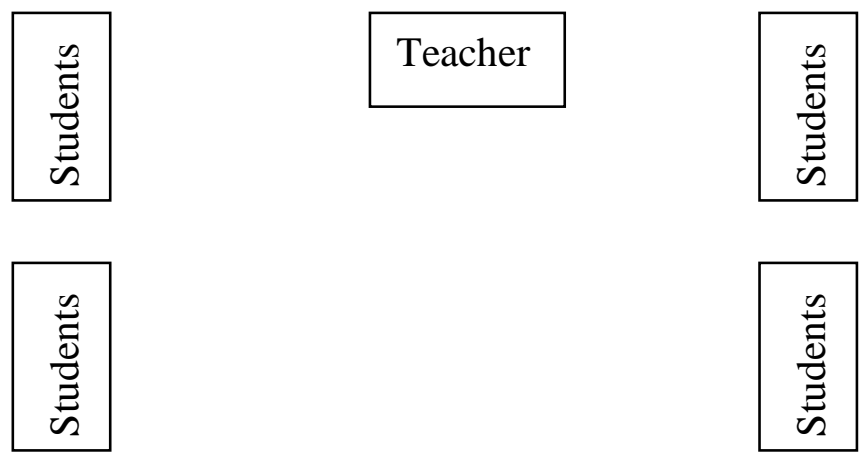


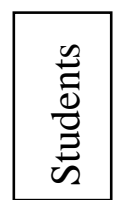

\section{Students}
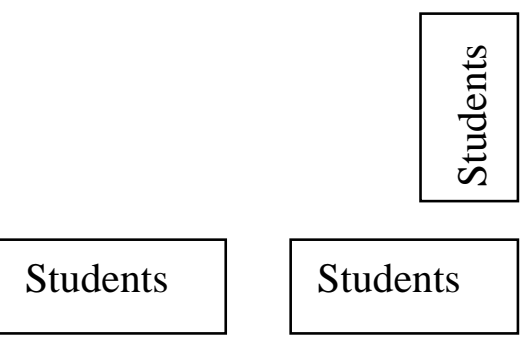

Students

Figure 2: Horseshoe, half-circle or U chair setting

\section{Full-circle chair setting}

The full-circle chair setting is also useful for language practice whether for a pair work or for a little extent for a group work. Teachers may go anywhere including at the center of the circle. As the previous chair setting, the position of teachers is flexible. They can play their roles as moderator, motivator, integrator, facilitator, and others. Students are also able to face-to-face interact with their friends so they can join in monologue or dialog, in transactional or interactional situations.

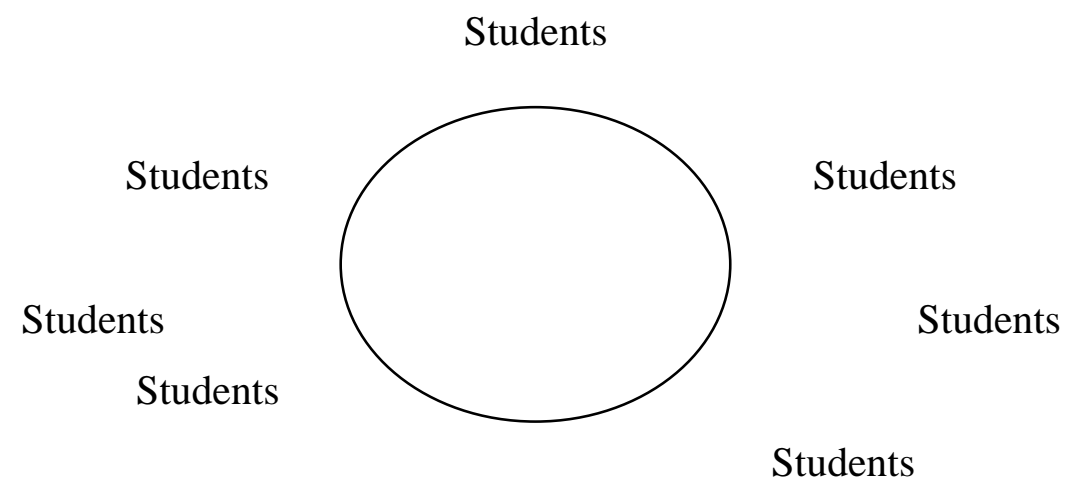

Students

Figure 3: Full circle chair setting 
4. Circle to circle or group to group chair setting

This is particularly useful for the group work of discussion before they report the results of group discussion, for example, in plenary sessions. Similarly, teachers are able to move anywhere to promote and stimulate students to be active in the discussion. The roles of teachers in this class setting can be intensified. They can move inside or outside, approach one group to motivate and leave the group for motivating the other ones. Besides for discussion it is possible for debates. The pros and the cons can face-toface agree or disagree and argue among others. They can share and articulate their ideas freely and academically.

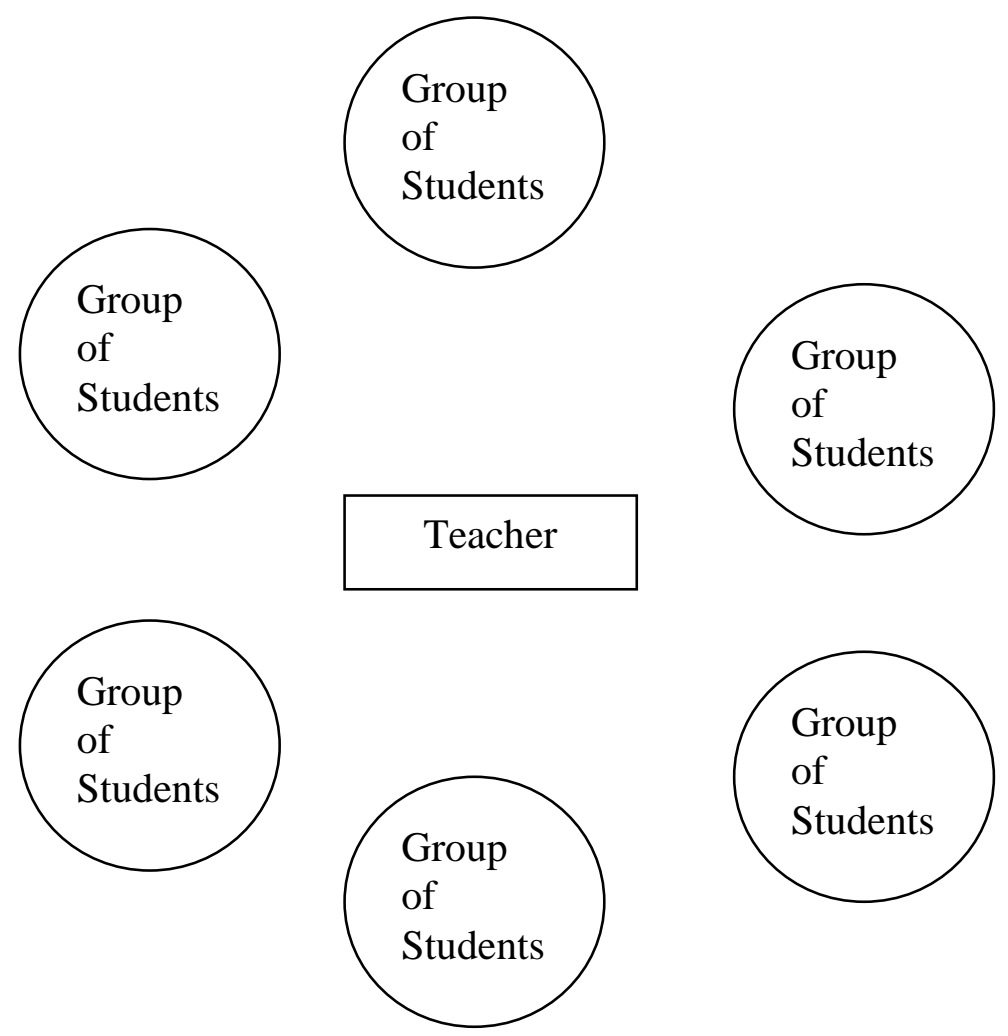

Figure 4: Circle to circle or group-to-group chair setting After chairing students, teachers are able to make decisions. According to Scrivener (1994), decisions are about whether teachers should 
do or not to do these actions, when they should do them, how should do them, and who should do the actions. The divisional activities are the teachers' choices or options to do. The essential basic skill for classroom management is therefore to be able to recognize options available to you, to make appropriate decisions among the options, and to turn them into effective and efficient actions. Your experience will grow as your awareness starts growing.

Options exist and are available in each point-to-point lessons. Teachers posses the points to say or not say differently. They may begin, proceed, or stop the class activity because they have options. They also may take a rest for a few while for preparing questions and answers just for clarifications. The options go throughout their lessons with no constraints except the time allotment they posses. In another classroom activity they also posses the same options to say something or nothing. The options also cover their responsibility to manage classroom for their own job - teaching. Therefore, they can choose any forms of class setting based on the teaching strategies applied. The form of the class should only be adjusted with what are the advantages and disadvantages of applying such class setting. Harmer (2001) calls that teachers have no limit to group or for some extent not to group students in their class activities. The task may be addressed for individual, pair, and group students. Therefore, the choice of the class setting must be dependent on the addressee development and achievement.

When teachers choose group work, there must be clear step to do as the following:

1. They should divide a large group of the class into small groups, usually of about five.

2. They should provide a task designed ahead of time for the small group to work on. 
3. They reconvene students into a plenary session to hear reports from the small groups and, acting as referees, help students negotiate a consensus of the class as a whole.

4. Acting as the class's local representative of a larger relevant knowledge community, they lead students to compare the class's plenary consensus with the current consensus of the knowledge community that the teacher's represent.

5. They should assess explicitly the quality of students' work (Bruffee, 1999:21).

\section{The Selection of Methods and Strategies}

Realizing that teaching speaking in big classes is difficult; teachers need to select method or methods to be used. The selection of the methods has dual purposes. The first is what methods that are suitable for being used in speaking class. This first purpose advocates the consideration of the second purpose of method selection. In this stage, the teachers should consider critically what kind of methods that is appropriate to be used for teaching speaking in such big class situations.

Concerning language-teaching methods, linguists and practitioners offer several models since the modern and scientific study of language started; some methods review the underlying theories of the nature of language, theories of learning, and practical stratagems to the teaching presentations. Some others offer the detail discussion of the theories of language learning and pace-to-pace presentation with a little attention to linguistics theories.

In terms of teaching speaking, teachers are free to consider the use of methods. Let me say that they are able to make use Direct Method, Oral Approach, Audiolingual Method, CLT, Total Physical Response, The Silent 
Way, Community Language Learning, The Natural Approach, or Suggestopedia. For big classes, however, they could not use them all because not all the methods and approaches are suitable for the big classes. For this, they may use CLT, CLL, The Natural Approach, or Suggestopedia.

Besides the two considerations, teachers need to oversee the other considerations attach to the teaching of speaking. These are important to consider seeing whether pronunciation and grammar are the paramount or just for facilities in speaking skills. How vocabularies are seen in the methods and how the design of students roles in such teaching is. Such considerations must be taken into account well because teachers should give greater portions to students to self-express ideas. For the purposes, they could not put all the methods at the same places. Therefore, they may choose CLT sometime, but CLL for the other occasion. Similarly, they may be better to choose Direct Method for early beginners and the like.

Considering methods are as important as considering teachinglearning strategies. To do with the stage teachers need to carefully see the level of students whether they are elementary, first secondary, secondary or university students. Then, they should reflect the learning activities models. In this term, they need to redesign whether the class work is individual, pair, or group. By the considerations, they are able to choose the appropriate teaching-learning strategies.

\section{Course presentation}

Teachers should speak little but students should do a lot. Wider room for language expressions and bigger portions of language use should be set in the course presentation. Teachers need to give stimulations to students for the expressions so the class will be theirs. When the class work stops teachers must be ready to initiate and provide language clues for students. It is 
possible to have written exemplifications to be used by students if they loss their stocks of questions. Because teachers' portion in speaking class is lesser, the time allotment should be divided proportionally. The proportion of the teachers' opportunity in one meeting can be as follows:

1. Opening including for calling the roll and approaching is about 10 minutes long.

2. The speaking practice including teachers' facilitation, help, and stimulation is more or less 75 minutes long.

3. The closing; including assigning students, motivating, and suggesting them for successful study, is about 15 minutes.

Such divisions are just in $2 \times 50$ minutes time allotment with 40 students in the class. The class activity can be intensified by grouping students into several divisions, take for instance 8 groups. Each group consists of five students and above is sometimes ineffective and inefficient because students tend to gossip or talk about something outside the topics. Thus, each student has 15 minutes long to speak with their friends. To improve, teachers may apply counseling language learning so students must assist one another for language use. They are to not only sympathize with their friend problems but also empathize by self-improvements and corrections.

The possible procedures of teaching speaking can be as follows:

1. Pre-teaching activities

In the pre teaching activities, teachers should demonstrate their selfaffections to their students by several teachers' actions as salutation, calling the roll of each student, asking students' state of health - including their families if possible, reminding students concerning their responsibility in the speaking study, motivating them, reviewing the previous materials for 
warming up and preparation, proposing new materials for discussion, and grouping.

\section{Whilst-teaching activities}

In this stage, teachers ask students to start discussing the topics. To help students, they may provide speaking clues and share to the students. When they find out the students keep silent they may help to provide the language expressions they want to say. The next facilitation and control are needed if the class has gone on and end the class when the bell rings.

\section{Post-teaching activities}

At this last step, teachers extend additional clarifications for the class. This is more to share and self-argue of the topics discussed rather than to justify. Besides, they motivate students to keep study and practice by showing the importance of speaking skills. At the end, they may assign students to group work and report the result of their discussions in the next class discussions.

The work of the class previously offered may polarize depends on the teachers' styles. They are able to give extensional improvement and development of the stages if they lack of individual taste. Likewise, they may also simplify or modify for simplicity. The matter is the presentation of the speaking class should accommodate students' necessity for self-actualize. This is teachers' job to do to create such an atmosphere.

\section{Conclusion}

Teaching speaking in difficult circumstance is more problematic than that of speaking in warmer-conducive class situations. Teachers' responsibility, as a matter of fact, is harder because the class design starts from the very beginning. They are not only to choose the best topics to be discussed but also to reflect how the topics are presented in the class actions. Reflecting the presentation of instructional materials becomes the central 
issue to make the speaking class works efficiently and affectively. The problem will be different if the class only consists of a few students. The coming problem is easier than the former.

There are several responsibilities of teachers for conducting creative speaking class. The first, teachers need to take account the students' existing skills. The possessed skills are used to predict the materials and teaching learning activities. After diagnosing the existing skills, they must engage to analyze their need. This functions to specify the objectives achieved. Then, the teachers should ask the class interactions to intensify student-selves actualization in oral expressions. The better the class is designed, the better the speaking class will be and the better the result of the class. To create the interactive speaking class, the teachers also need to select methods and learning strategies because each method has specific emphasis and each strategy offers specific model for language presentation. At the end, they should design the simple speaking class by which the bigger portions of time should be given to students and the least time allotment can be used for clarification and motivations for students' advancement.

Those efforts are designed to create interactive speaking class to yield the satisfactory results. Equipping students with this skill is important because speaking becomes the short measurement target and parameter of language proficiency. Students' ability in the language use will be understood soon after the co-listeners listen to the proposed ideas extended. Because speaking skill is the most visible language parameter, efforts should be done to achieve the goal. The previous discussions can be the starting points for improving speaking skills in the big and difficult circumstances. 


\section{References}

Bruffee, Kenneth A. 1999. Collaborative Learning. Higher Education, Interdependence, and the Authority of Knowledge. Baltimore and London: The Johns Hopkins University Press.

Graves, Kathleen. 1996. Teachers as Course Developers. Cambridge: Cambridge University Press.

Harmer, Jeremy. 2001. The Practice of English Language Teaching. UK : Longman.

Harris, David P. 1969. Testing English as a Second Language. New York: McGraw-Hill Book Company.

Nunan, David. 1989. Designing Tasks for the Communicative Classroom. Cambridge: Cambridge University Press.

Richards, Jack C. and S. Rodgers, Theodore. 1992. Approaches and Methods in Language Teaching: A description and analysis. Cambridge: Cambridge Language Teaching Library.

Scrivener, Jim. 1994. Learning Teaching: A guidebook for English language teachers. Oxford: Heinemann.

West, Michael. 1966. Teaching English in Difficult Circumstances. London, Great Britain: Lowe and Brydone Ltd. 